\title{
BOOKS RECEIVED/LIVRES RÉÇUS
}

Allen, Louisa, Young People and Sexuality Education: Rethinking Key Debates. New York: Palgrave Macmillan, 2011, 208 pp. \$US 80.00 hardcover (978-0-230-57943-9)

Atkinson, Will, Class, Individualization and Late Modernity: In Search of the Reflexive Worker. Identity Studies in the Social Sciences. New York: Palgrave Macmillan, 2010, 272 pp. \$US 85.00 hardcover (978-0-23024200-5)

Baiocchi, Gianpaolo, Patrick Heller, and Marcelo K. Silva, Bootstrapping Democracy: Transforming Local Governance and Civil Society in Brazil. Stanford: Stanford University Press, 2011, 224 pp. \$US 21.95 paper (978-0-8047-6056-0), \$US 65.00 hardcover (978-0-8047-6055-3)

Bandelj, Nina and Frederick F. Wherry, eds., The Cultural Wealth of Nations. Stanford: Stanford University Press, 2011, 296 pp. \$US 24.95 paper (978-0-8047-7645-5), \$US 80.00 hardcover (978-0-8047-7644-8)

Bell, Emma, Criminal Justice and Neoliberalism. New York: Palgrave Macmillan, 2011, 240 pp. \$US 85.00 hardcover (978-0-230-25197-7)

Benzecry, Claudio E., The Opera Fanatic: Ethnography of an Obsession. Chicago: University of Chicago Press, 2011, 256 pp. \$US 29.00 paper (9780-226-04342-5), \$US 85.00 hardcover (978-0-226-04340-1)

Bockman, Johanna, Markets in the Name of Socialism: The Left-Wing Origins of Neoliberalism. Stanford: Stanford University Press, 2011, 352 pp. \$US 55.00 hardcover (978-0-8047-7566-3)

Borch, Christian, Niklas Luhmann. Key Sociologists. New York: Routledge, 2011, 166 pp. \$US 49.95 paper (978-0-415-49094-8), \$US 125.00 hardcover (978-0-415-49093-1)

Bradley, Tamsin, Religion and Gender in the Developing World: Faith-Based Organizations and Feminism in India. Library of Development Studies (Tauris Academic Studies). New York: Palgrave Macmillan, 2011, 272 pp. \$US 92.00 hardcover (978-1-84885-427-7)

Bramham, Peter and Stephen Wagg, eds., The New Politics of Leisure and Pleasure. New York: Palgrave Macmillan, 2011, 320 pp. \$US 30.00 paper (978-0-230-21684-6), \$US 95.00 hardcover (978-0-230-21683-9)

Carlson, Marcia J. and Paula England, eds., Social Class and Changing Families in an Unequal America. Stanford: Stanford University Press, 2011, 248 pp. \$US 24.95 paper (978-0-8047-7089-7), \$US 80.00 hardcover (978-0-8047-7088-0) 
Demeulenaere, Pierre, ed., Analytical Sociology and Social Mechanisms. New York: Cambridge University Press, 2011, 330 pp. \$US 32.99 paper (9780-521-15435-2), \$US 90.00 hardcover (978-0-521-19047-3)

Domhoff, G. William and Michael J. Webber, Class and Power in the New Deal: Corporate Moderates, Southern Democrats, and the Liberal-Labor Coalition. Stanford: Stanford University Press, 2011, 304 pp. \$US 24.95 paper (978-0-8047-7453-6), \$US 80.00 hardcover (978-0-8047-7452-9)

Dyson, Tim, Population and Development: The Demographic Transition. New York: Zed Books, 2010, 272 pp. \$US 28.95 paper (978-1-84277-960-6), \$US 125.95 hardcover (978-1-84277-959-0)

Fox, Robin, The Tribal Imagination: Civilization and the Savage Mind. Cambridge, MA: Harvard University Press, 2011, 432 pp. \$US 29.95 hardcover (978-0-674-05901-6)

Giroux, Henry A., Youth in a Suspect Society: Democracy or Disposability? New York: Palgrave Macmillan, 2010, 256 pp. \$US 28.00 paper (978-0230-10870-7), \$US 40.00 hardcover (978-0-230-61329-4)

Gunter, Barrie, Anders Hansen, and Maria Touri, Alcohol Advertising and Young People's Drinking: Representation, Reception and Regulation. New York: Palgrave Macmillan, 2010, 248 pp. \$US 85.00 hardcover (978-0-230-23753-7)

Hassan, Riaz, Suicide Bombings. Shortcuts. New York: Routledge, 2011, 116 pp. \$US 29.95 paper (978-0-415-58887-4), \$US 100.00 hardcover (978$0-415-58886-7)$

Illomen, Kaj, Pekka Sulkunen, Keijo Rahkonen, Jukka Gronow, and Arto Noro, A Social and Economic Theory of Consumption. Translation by David Kivinen. New York: Palgrave Macmillan, 2011, 256 pp. \$US 85.00 hardcover (978-0-230-24410-8)

Isitt, Benjamin, Militant Minority: British Columbia Workers and the Rise of a New Left, 1948-1972. Toronto: University of Toronto Press, 2011, 424 pp. \$35.00 paper (978-1-4426-1105-4), \$75.00 hardcover (978-1-44264194-5)

Kellogg, Katherine C., Challenging Operations: Medical Reform and Resistance in Surgery. Chicago: University of Chicago Press, 2011, 248 pp. \$US 25.00 paper (978-0-226-43003-4), \$US 75.00 hardcover (978-0226-43002-7)

Kessler, Kelly, Destabilizing the Hollywood Musical: Music, Masculinity and Mayhem. New York: Palgrave Macmillan, 2010, 240 pp. \$US 85.00 hardcover (978-0-230-23049-1)

Kezar, Adrianna J. and Jaime Lester, Enhancing Campus Capacity for Leadership: An Examination of Grassroots Leaders in Higher Education. Stanford: Stanford University Press, 2011, 368 pp. \$US 60.00 hardcover (978-0-8047-7647-9) 
Kirchengast, Tyrone, The Criminal Trial in Law and Discourse. New York: Palgrave Macmillan, 2010, 272 pp. \$US 85.00 hardcover (978-0-23057785-5)

Knott, Kim and Sean McLoughlin, eds., Diasporas: Concepts, Intersections, Identities. New York: Zed Books, 2010, 304 pp. \$US 41.95 paper (978-184277-948-4), \$US 125.00 hardcover (978-1-84277-947-7)

Kobek, Jarett, ATTA. Semiotext(e). Cambridge, MA: MIT Press, 2011, 200 pp. \$US 12.95 paper (978-1-58435-10).

LaRossa, Ralph, Of War and Men: World War II in the Lives of Fathers and Their Families. Chicago: University of Chicago Press, 2011, 328 pp. \$US 32.00 paper (978-0-226-46743-6), \$US 96.00 hardcover (978-0226-46742-9)

Lewis, Jeff, Crisis in the Global Mediasphere: Desire, Displeasure and Cultural Transformation. New York: Palgrave Macmillan, 2011, 240 pp. \$US 85.00 hardcover (978-0-230-24742-0)

Marazzi, Christian, Capital and Affects: The Politics of the Language Economy. Semiotext(e). Translated by Giuseppina Mecchia. Cambridge, MA: MIT Press, 2011, 160 pp. \$US 15.95 paper (978-1-58435-103-0), \$ hardcover ()

McAlpine, Lynne and Gerlese Akerlind, Becoming an Academic: Universities into the 21st Century. New York: Palgrave Macmillan, 2010, 208 pp. \$US 36.00 paper (978-0-230-22791-0)

McBride, Stephen and Heather Whiteside, Private Affluence, Public Austerity: Economic Crisis and Democratic Malaise in Canada. Halifax: Fernwood Publishing, 2011, 192 pp. \$24.95 paper (978-1-55266-403-2), \$49.95 hardcover (978-1-55266-430-8)

Montigny, Edgar-Andre, ed., The Real Dope: Social, Legal, and Historical Perspectives on the Regulation of Drugs in Canada. Toronto: University of Toronto Press, 2011, 352 pp. $\$ 35.00$ paper (978-0-8020-9655-5), $\$ 85.00$ hardcover (978-0-8020-9942-6)

Moore, Sian, New Trade Union Activism: Class Consciousness or Social Identity?. New York: Palgrave Macmillan, 2011, 208 pp. \$US 80.00 hardcover (978-0-230-24411-5)

Mutz, Diana C., Population-Based Survey Experiments. Princeton, NJ: Princeton University Press, 2011, 192 pp. \$US 24.95 paper (978-0-691-144528), \$US 49.50 hardcover (978-0-691-14451-1)

Panke, Diana, The Effectiveness of the European Court of Justice: Why Reluctant States Comply. Manchester, UK: Manchester University Press, 2011, 256 pp. \$US 95.00 hardcover (978-0-7190-8306-8)

Parkin, David and Stanley Ulijaszek, eds., Holistic Anthropology: Emergence and Convergence. Volume 16, Methodology \& History in Anthropology. New York \& Oxford: Berghahn Books, 2011, 224 pp. \$US 29.95 paper (978-0-85745-152-1), \$US 90.00 hardcover (978-1-84545-354-1) 
Petras, James and Henry Veltmeyer, Social Movements in Latin America: Neoliberalism and Popular Resistance. Social Movements and Transformation. New York: Palgrave Macmillan, 2011, 286 pp. \$US 85.00 hardcover (978-0-230-10411-2)

Pini, Barbara and Belinda Leach, eds., Reshaping Gender and Class in Rural Spaces. Gender in a Global/Local World. Aldershot: Ashgate, 2011, 266 pp. \$US 114.95 hardcover (978-1-4094-0291-6)

Poggi, Gianfranco and Giuseppe Sciortino, Great Minds: Encounters with Social Theory. Stanford: Stanford University Press, 2011, 192 pp. \$US 21.95 paper (978-0-8047-7214-3), \$US 65.00 hardcover (978-0-80477213-6)

Raisborough, Jayne, Lifestyle Media and the Formation of the Self. New York: Palgrave Macmillan, 2011, 192 pp. \$US 80.00 hardcover (978-0-23024295-1)

Richardson, John G. and Justin J.W. Powell, Comparing Special Education: Origins to Contemporary Paradoxes. Stanford: Stanford University Press, 2011, 360 pp. \$US 60.00 hardcover (978-0-8047-6073-7)

Romanienko, Lisiunia A., Body Piercing and Identity Construction: A Comparative Perspective - New York, New Orleans, Wroclaw. New York: Palgrave Macmillan, 2011, 280 pp. \$US 85.00 hardcover (978-0-23011032-8)

Rosenthal, Jean-Laurent and R. Bin Wong, Before and Beyond Divergence: The Politics of Economic Change in China and Europe. Cambridge, MA: Harvard University Press, 2011, 290 pp. \$US 45.00 hardcover (978-0674-05791-3)

Rouncefield, Mark and Peter Tolmie, eds., Ethnomethodology at Work. Directions in Ethnomethodology and Conversation Analysis. Aldershot: Ashgate, 2011, 278 pp. \$US 114.95 hardcover (978-0-7546-4771-3)

Shah, Rebecca, ed., The International Migration of Health Workers: Ethics, Rights and Justice. New York: Palgrave Macmillan, 2011, 256 pp. \$US 85.00 hardcover (978-0-230-22441-4)

Sreberny, A. and G. Khiabany, Blogistan: The Internet and Politics in Iran. London: I.B. Tauris, 2010, 240 pp. \$US 27.50 paper (978-1-84511-6071), \$US 75.00 hardcover (978-1-84511-606-4)

Susen, Simon and Bryan S. Turner, eds., The Legacy of Pierre Bourdieu: Critical Essays. New York: Anthem Press, 2011, 470 pp. \$US 130.00 hardcover (978-0-85728-768-7)

Sutton, Sharon E. and Susan P. Kemp, eds., The Paradox of Urban Space: Inequality and Transformation in Marginalized Communities. New York: Palgrave Macmillan, 2011, 296 pp. \$US 90.00 hardcover (978-0-23010391-7) 
Tiqqun, This is Not a Program. Semiotext(e)/Intervention. Translated by Joshua David Jordan. Cambridge, MA: MIT Press, 2011, 200 pp. \$US 13.95 paper (978-1-58435-097-2),

Urry, John, Climate Change and Society. Oxford: Polity Press, 2011, 200 pp. \$24.95 paper (978-0-7456-5037-1), \$76.95 hardcover (978-0-74565036-4)

van den Hoonaard, Will C., The Seduction of Ethics: Transforming the Social Sciences. Toronto: University of Toronto Press, 2011, 392 pp. \$32.95 paper (978-1-4426-1150-4), \$75.00 hardcover (978-1-4426-4268-3)

Walker, Stephen G. and Akan Malici, U.S. Presidents and Foreign Policy Mistakes. Stanford: Stanford University Press, 2011, 360 pp. \$US 29.95 paper (978-0-8047-7499-4), \$US 100.00 hardcover (978-0-8047-7498-7)

Waugh, Earle H., Olga Szafran, and Rodney A. Crutcher, eds., At the Interface of Culture and Medicine. Edmonton: University of Alberta Press, 2011, pp. \$49.95 paper (978-0-88864-532-6)

White, Mark D., Kantian Ethics and Economics: Autonomy, Dignity, and Character. Stanford: Stanford University Press, 2011, 288 pp. \$US 55.00 hardcover (978-0-8047-6894-8) 